\title{
CREATING INTEREST IN STUDENTS TOWARDS BASIC SCIENCE
}

\author{
A. P. Radhakrishna*
}

\begin{abstract}
Science and technology are the two wheels of a progressive society. While the research in basic science brings the growth of technology, the developments in technology add input to the diverse fields of science. Basic science is the soul of technology. But it is a sorry state of affair that at present the inferest in basic science courses such as Physics, Chemistry, Mathematics and Biology is dwindling among the students. If the trend continues, it will hamper the growth of the nation in all spheres, including the technological front too. The paper tries to highlight the different reasons for this trend and the future implicarions.

Recently the United Nations announced that the Year 2005 will be celebrated as the 'International Year of Physics' to remember the great discoveries made by Albert Einstein in the year 1905. If was hundred years ago, in 1905, that he published three historic papers in Annalen der Physik which brought out a revolution and a new dimension to Physics in particular and Science in general. Also the year 2005 will be celebrated as the golden year of the discovery of DNA structure by Watson' and Crick in 1955. Such celebrations should be a mass movement. The struggle and joy of the great discoveries by great minds should reach to the young minds. This will kindle the interest in them towards Basic Science courses. In the long run the nation will be benefited. It is now the time for responsible men - teachers, parents, educationists,
\end{abstract}

\footnotetext{
* Dept. of Physics, Vivekananda College, Puttur - 574203.
} 
technocrats, media persons and the people in the helm of affairs to discuss the situation prevailing in the field of higher education of basic Science and look for the meaningful solution.

The paper also elaborates the in-depth programme conducted by Vivekananda College, Puttur, for the past fiffeen years, creating interest among the students of rural schools of the region towards Science.

\section{Introduction}

Often it is boastfully said that India has the third largest scientific and technical manpower in the world: But, more than the number, the quality is important. In recent years it has become a subject of constant discussion in the academic circles that the science education is declining in the country. The research publications from India in the reputed journals of higher Science Citation Index (SCI) are downward, while there is an upward trend in the case of China, and even in case of small countries such as Korea and Taiwan.

If science has to be created, it is to be created by the young minds. But most of the bright youngsters are now moving away from basic science. It is rightly said by Dr. CNR Rao, an eminent Scientist, "unless we do something serious, I am atraid that we will soon become a third rate country in science." Dr. Jayanth Narlikar, a renown astrophysicist, has deplored the decline on the part of students community in pursuing studies in the pure sciences which are essential for conducting fundamental research, the backbone of technology. "Today a student .... goes by default to engineering, medicine or ... commerce in contrast to the scenario that existed in the fifties and sixties when many of our science laboratories, departments and universities were getting established. "2

The country needs the young and enthusiastic brilliant minds in defence, space, atomic energy, biotechnology, agriculture and in many other fields. The factories can't create them. They have to be nurtured in our schools and colleges. But it is not happening at the level which it has to happen. Therefore science institutes and centres in the country are already feeling the pinch by not getting enough bright students of high creativity. ${ }^{3}$

Science and Technology are the two wheels of a progressive society. If Science discovers the laws of nature, these laws are applied in Technology. The development of technology gives new input to the scientific research. One can't abandon the basic science and anticipate the advancement in technology. Can we imagine the engineering without mechanics which was developed by Galileo, Newton and 
others? Can we run a nuclear reactor without the basics of nuclear science developed by Rutherford and Fermi? Is it possible to manufacture new drugs if one does not know the mechanism of various reactions? The point is that we can't deny the need of basic science.

The time has come for educationists, planning members, teachers, parents and persons at the helm of affairs to make serious introspection and deliberations about the grave problems prevailing in the higher education in general and basic science education in particular and then plunge in to action. Only this can save the basic sciences in the field of higher education.

\section{Burning Problems}

There has been a phenomenal growth of Universities and higher education centres in the country since Independence. There are now 185 universities, 42 deemed universities and five institutions established through State and Central legislation, and nearly 11,100 colleges in the country in addition to the large number of unrecognized institutions in the higher education sector. More than 6000 colleges offer the Science education.' The following table summarizes the magnitude of education in this huge country.

Number of Recognized Educational Institutions in India (1998-99)

\begin{tabular}{|l|l|r|r|r|r|r|r|}
\hline $\begin{array}{l}\text { No. } \\
\text { No. States/ UTs }\end{array}$ & $\begin{array}{c}\text { Primary } \\
\text { Junior } \\
\text { Basic } \\
\text { Schools }\end{array}$ & $\begin{array}{r}\text { Middle/ } \\
\text { Senior } \\
\text { Basic } \\
\text { Schools }\end{array}$ & $\begin{array}{r}\text { High Sch./ } \\
\text { Hr. Sec. } \\
\text { intermediate/ } \\
\text { Pre-degree/ } \\
\text { Jr College }\end{array}$ & $\begin{array}{r}\text { Colleges } \\
\text { for } \\
\text { Eeneral } \\
\text { Education }\end{array}$ & $\begin{array}{r}\text { Professional } \\
\text { Education }\end{array}$ & $\begin{array}{l}\text { Universities/ } \\
\text { Deemed } \\
\text { Uni. and } \\
\text { Inst. of } \\
\text { National } \\
\text { Importance }\end{array}$ \\
\hline 1. & Andhra Pradesh & 51836 & 8713 & 11225 & 923 & 189 & 20 \\
2. & Arunachal Pradesh & 1277 & 326 & 171 & 7 & 1 & 1 \\
3. & Assam & 33236 & 8019 & 4590 & 265 & 33 & 6 \\
4. & Bihar & 53697 & 13761 & 4910 & 742 & 74 & 17 \\
5. & Goa & 1042 & 98 & 436 & 21 & 10 & 1 \\
6. & Gujarat & 14789 & 20044 & 6011 & 339 & 109 & 11 \\
7. & Haryana & 10269 & 1788 & 3785 & 169 & 45 & 5 \\
8. & Himachal Pradesh & 7732 & 1189 & 1525 & 57 & 6 & 3 \\
9. & Jammu \& Kashmir & 10483 & 3104 & 1351 & 38 & 12 & 3 \\
\hline
\end{tabular}




\begin{tabular}{|c|c|c|c|c|c|c|c|}
\hline \begin{tabular}{|l} 
SI. \\
No.
\end{tabular} & Stafes/ UTs & $\begin{array}{l}\text { Primary } \\
\text { Junior } \\
\text { Basic } \\
\text { Schools }\end{array}$ & $\begin{array}{l}\text { Midde/ } \\
\text { Senior } \\
\text { Basic } \\
\text { Sdhools }\end{array}$ & $\begin{array}{l}\text { High Sch./ } \\
\text { Hr.Sec. } \\
\text { Intermediate/ } \\
\text { Pre-degree/ } \\
\text { JrCollege }\end{array}$ & $\begin{array}{c}\text { Colleges } \\
\text { for } \\
\text { General } \\
\text { Education }\end{array}$ & $\begin{array}{l}\text { Professiona } \\
\text { Education }\end{array}$ & $\begin{array}{l}\text { Universities } \\
\text { Deemed } \\
\text { Uni. and } \\
\text { Instt. of } \\
\text { National } \\
\text { Importance }\end{array}$ \\
\hline 10. & Karnataka & 23690 & 24142 & 10073 & 838 & 346 & 15 \\
\hline 11. & Kerala & 6755 & 2966 & 3109 & 186 & 42 & 9 \\
\hline 12. & Madhya Pradesh & 86858 & 21108 & 8341 & 413 & 70 & 17 \\
\hline 13. & Maharashtra & 41804 & 22196 & 14471 & 838 & 538 & 26 \\
\hline 14. & Manipur & 2570 & 630 & 582 & 50 & 3 & 2 \\
\hline 15. & Meghalaya & 4679 & 946 & 493 & 33 & 1 & 1 \\
\hline 16. & Mizoram & 1244 & 741 & 378 & 27 & 2 & 0 \\
\hline 17. & Nagaland & 1469 & 470 & 295 & 29 & 1 & 1 \\
\hline 18. & Orissa & 42104 & 12096 & 6813 & 524 & 48 & 5 \\
\hline 19. & Punjab & 12633 & 2527 & 3325 & 193 & 64 & 5 \\
\hline 20. & Rajasthan & 35077 & 14807 & 5633 & 267 & 76 & 10 \\
\hline 21. & Sikkim & 501 & 131 & 108 & 2 & 1 & 1 \\
\hline 22. & Tamil Nadu & 30844 & 5538 & 7357 & 365 & 174 & 21 \\
\hline 23. & Tripura & 2065 & 414 & 589 & 16 & 4 & 1 \\
\hline 24. & Uttar Pradesh & 94476 & 20675 & 8339 & 676 & 174 & 28 \\
\hline 25. & West Bengal & 52123 & 2864 & 6652 & 389 & 66 & 14 \\
\hline 26. & A\&N Islands & 188 & 51 & 82 & 2 & 1 & 0 \\
\hline 27. & Chandigarh & 48 & 34 & 107 & 12 & 7 & 2 \\
\hline 28. & D\&N Haveli & 144 & 54 & 15 & 0 & 0 & 0 \\
\hline 29 & Daman \& Diu & 53 & 22 & 25 & 1 & 1 & 0 \\
\hline 30. & Delhi & 2676 & 601 & 1459 & 64 & 24 & 11 \\
\hline 31. & Lakshadweep & 19 & 4 & 13 & 0 & 0 & 0 \\
\hline 32. & Pondicherry & 356 & 107 & 175 & 8 & 7 & 1 \\
\hline & INDIA & 626737 & 190166 & 112438 & 7494 & 2129 & 237 \\
\hline
\end{tabular}

Source: Annual Report 1999-2000, Ministry of HRD, Government of India ${ }^{5}$ 
It was estimated that less than one percent of the students complete $10+2$ school years and go on to Science education at the College level. Though the total number of students in all three years of undergraduate courses has increased from $1,28,000$ in 1950 to $7,25,000$ in the late eighties, the percentage of the total student population choosing science after school has dropped over the same period from $32 \%$ to $19 \%{ }^{4}$..

There may be various reasons for the lack of interest shown by students towards the basic science, after the pre university education. The most common reason is that an excess thrust has been given by the Government in recent years to professional courses at the expense of the basic science.

It is true that compared to any other professional course, the prospects appear pretty gloomy in basic science. Plenty of job opportunities, hefty salary, vertical and horizontal mobility available in the industries and management sectors have drawn the young minds fowards these professional courses. The mentality of society also plays here the major role. The parents feel that the basic science is not rewarding. CV Raman, Ramanujan, Einstein, Bohr, Pasture and Jenner are no longer the role models. ${ }^{6}$

The government also adds plenty of fuel to the burning problems. By stating financial constraints, the Government simply shakes its shoulders by saying "no approval of new post even if it is generated due to the retirement". The policy of Government has created three classes of lecturers in a College - lecturers of highly paid UGC scale, lecturers of moderately paid state scale and then permanently temporary lecturers of a meagre scale paid by the management. It is irony that all possess equal qualification and do have the same workload. Then what quality can one expect from this ufter disparity?

The Colleges virtually do not receive any funds from the Government. Funds are required for the development of infrastructure, procuring equipment, adding new instruments to the laboratory. But the Government does not care for the appalling conditions of the colleges. Still worse is the fact that the Government is thinking seriously to stop whatever the financial grants it has been giving to the private Colleges. It is true that, at present if good science education available, it is available only in private colleges. If the government stops the grant in aid, then most of these colleges have either to close science education or to hike the fees. If the fee is increased, can we expect more turn out? What about the fate of the Colleges existing in the rural area?

When we speak about the declining of interest towards the basic science, quality in education, we have to consider all these burning issues. After keeping aside these 
problems to pile up, it may be an Utopian idea to expect excellence in higher education. If basic science is not nurtured in the academic institutions there is a little hope that good applied or applicable science will emerge in the future. ${ }^{7}$

\section{Begin at School}

The science education at undergraduate level is part of a continuum, starting education at school level and going on to research in science. Therefore it is required to strengthen it at primary and high school. It is estimated that the number of school going students was about 12 crores in 1985 and has been continuously increasing at $3 \%$ per year. ${ }^{4}$ The number of well equipped schools in terms of laboratories, library and competent teachers are extremely small. However, it is fortunate that a vast majority of schools have not lost hope and are trying their best to create interest among students in science.

The need of science and the career in science are to be clearly emphasized in the school level. The demonstration of experiments, the field visits, other related activities will create real interest in students towards science. In this connection the Colleges can take an active part. I give an example of Vivekananda College, Puttur, where l am now working. The College is situated in a rural area. From 1985 onwards the Science Departments of the College has been conducting an "in depth programme" for the rural schools of the region. Every year in the month of January, the programme is conducted for three to four days. More than $\mathbf{4 0 0}$ students from selected schools are invited to participate. They visit all the laboratories in the College, where various experiments are demonstrated by the lecturers and students. The enthusiasm and interest of the visiting students are really amazing. Such programmes can be conducted in every College which would really bring a new vigour in science education.

The Science Departments of Colleges can also think of a "Mobile Science Unit", where some equipment can be taken in a van to the village school and demonstrate simple experiments and explain the different aspects of science. Such activities may help in creating the real interest in students towards science.

\section{Nurturing Talents}

There are a few efforts and hopes to revive the basic science education. Recently the Government has initiated CV Raman Scholarship to the students pursuing BSC course who score more than $70 \%$ marks in Pre University exams. Many students in our college have received the scholarship. The Young Scientist Programme - Kihore 
Vijyanik Protsahan Yojana - is also an excellent programme launched in the year by the Government of India. It is to encourage students of the Sciences, Engineering and Medicine to take up careers in research in these fields. The selected students will be given a good amount of scholarship for their post graduation. They will do summer project with scientists in the reputed institutes such as $\| \mathrm{Sc}$, Bangalore, TIFR, Bombay. This type of recognition is the need of the hour and let us hope it will be continued. Here, probably, the private sectors can join hand with the Government. Recently Wipro has launched one such programme to select the Mathematical wizard of the country.

Scientists from premier institutes can spare some time to deliver lectures at colleges and enlighten the students about the prospects of science. Their presence will be a lasting impression on the students. In association with Indian Academy of Sciences, the University and some of the colleges are now arranging the refresher and orientation courses to the college teachers. It is a welcoming trend. It is still better, if they conduct such programmes for students, which will bring more interest in students towards science.

Indian performance in the recently concluded Olympics in Athens was really pathetic. But the Indian performance in the International Physics, Chemistry and Mathematics Olympiad over the years is excellent. This year International Physics Olympiad (IPhO) was held at Pohang, South Korea from July 15-23. All the five participants from India bagged the medal and India was ranked 9 among 71 participants. The performance shows that there is no dearth of talents. We have to spot them and nurture them. They will excel.

\section{Propagating Science}

Science should reach the general public. Therefore its popularisation by various means is necessary. The United Nations has announced that the year 2005 will be celebrated as the "International Year of Physics" to remember the great discoveries made by Albert Einstein in the year 1905. It was hundred years ago, in 1905, Einstein at very young age published three historic papers in Annalen der Physik which brought out a revolution and a new dimension to Physics in particular and Science in general. Also the year 2005 will be celebrated as the golden year of discovery of DNA structure by Watson and Crick in 1950. Each college and university has to celebrate such events which create awareness in students and general public.

Science is not stagnant. It develops with time. It is not simply the collection of equations, symbols, figures and calculations. It is a way of life developed over the years. Therefore wherever possible, the historic developments of the science ought 
to be mentioned - in the class and in texts. The serendipity in the discovery of $X$-ray, excitement in the discovery of radioactivity or penicillin, Lovis Pasture's remarkable career which paved the way to the field of Micro Biology and many other such stories would bring enthusiasm in students. Divorced from the past, modern science may seem to sterile. ${ }^{8}$ To attract and motivate the young minds, wherever possible romanticism of science should be highlighted.

\section{Restructuring the Courses}

To review the existing situation in University Science Education in India, the Council of Indian Academy of Sciences constituted a panel (1995) with eminent Scientists and educationists as its members. The panel prepared a well researched report which highlights the various problems of science education in the country and gives suggestions to solve these problems.

One such suggestion is to restructure the Course content in the College and University. They have suggested that instead of usual combinations such as Physics, Chemistry and Mathematics (PCM), or Botany, Zoology and Chemistry (BZC) the new combinations such as Physics, Mathematics and Biology or Biology, Mathematics and Computer Science can be introduced in B.Sc course. It is an excellent suggestion, since students find new choices. However, the panel was probably not aware that the Government is not welcoming these changes. If the college introduces new combination, that will not come under grant in aid. Even students are also not considered for the workload of the approved staff in the Department and the Department suffers. Thus by introducing new subjects in the degree courses, many Colleges have put themselves in jeopardy.

The panel also suggested the Three Tier system in the undergraduate science education. The Tier $l$ is aimed at highly talented group of students, around 700 , who will join for integrated M.Sc and PhD programme in top institutes such as ITT. $10.5 \%$ of the total of about $1,50,000$ students entering undergraduate science course each year.) The Tier ll aims at the next segment of the undergraduate science students, around 24,000 (about 16\%) will join the selected centres of excellence by UGC. Tier Ill comprises the remaining students in other colleges. All efforts should be imitated in great spirits and make these colleges improve. Probably the exercise of National Accreditation of Colleges (NAAC) aims at this direction. 
There are many other suggestions, such as

- Funding of colleges and universities must improve.

- Quality science education centres should be started at a few places af least.

- Accreditation of science departments in universities and colleges to be reviewed periodically.

- Wide publicity should be given to all educational opportunities and career opportunities in industry and elsewhere for science degree holders

- Academic cooperation between educational institution and national laboratories should be strongly encouraged, including joint research, teaching and adjunct positions

- New institutions or centres created should be within the overall university system, but administratively independent and autonomous.

If the suggestions of the panel are implemented, that would bring a new vigour to the basic science education. But, l am really not aware, how much of these suggestions have already been implemented. If they are not, it is worth to consider implementing them soon, so that we can have a ray of hope for the revival of basic science education in the country.

\section{References:}

1. Arunachalam, Subbiah, Science in india, Current Science, 2003, 84, No 3, p 259.

2. Norlikar JV, No Fizz and spark - decline in science education, Times of India, 1999, $6^{\text {th }}$ May, p 10.

3. Patil Rajashekha., Basic Science Eduacation in India, Current Science, 2003, 85, No 3, p 238.

4. University education in Science, Report by Indian Academy of Science, Current Science, 1995,68, No 3, p $255-267$.

5. www.ficci-sedf.org/fsedf/privateinitdiscuss4.htm

6. Joshi AW, Where are our CV Ramons? Current Science, 1995, 76, No 1, p 9.10.

7. Balaram P, Blue Sky Research, Current Science, 2003, 76, No 1, p 6-7.

8. Balaram P, History of Science, Current Science, 1998, 75, No 12, p 1285.86. 